\title{
Research on the effect of formononetin on photodynamic therapy in $\mathrm{K} 562$ cells
}

\author{
Dan Sun ${ }^{1}$, Yao Lu ${ }^{1}$, Su-juan Zhang ${ }^{1}$, Kai-ge Wang ${ }^{1}$ and Zhe Sun ${ }^{2}$ \\ ${ }^{1}$ National Center for International Research of Photoelectric Technology \& Nano-functional Materials, State Key Laboratory \\ of Cultivation Base for Photoelectric Technology and Functional Materials, Key Laboratory of Optoelectronic Technology of \\ Shaanxi Province, Institute of Photonics \& Photo-Technology Northwest University, Xian, 710069, China \\ ${ }^{2}$ Chang'an NO 10 Middle School of Xian, Xian, 710109, China
}

\begin{abstract}
At the present time, many cancer patients combine some forms of complementary and alternative medicine therapies with their conventional therapies. The most common choice of these therapies is the use of antioxidants. Formononetin is presented in different foods. It has a variety of biological activities including antioxidant and anti-cancer properties. On account of its antioxidant activity, formononetin might protect cancer cells from free radical damage in photodynamic therapy (PDT) during which reactive oxygen species (ROS) production was stimulated leading to irreversible tumor cell injury. In this study, the influence of formononetin on K562 cells in PDT was demonstrated. The results showed that formononetin supplementation alone did not affect the lipid peroxidation, DNA damage and apoptosis in K562 cells. It increases the lipid peroxidation, DNA damage and apoptosis in K562 cells induced by PDT. The singlet oxygen quencher sodium azide suppresses the apoptosis induced by PDT with formononetin. In conclusion, formononetin consumption during PDT increases the effectiveness of cancer therapy on malignant cells. The effect of antioxidants on PDT maybe was determined by its sensitization ability to singlet oxygen.
\end{abstract}

Key words: Formononetin - Reactive oxygen species - Photodynamic therapy — Sodium azide - Leukemia K562

\section{Introduction}

Photodynamic therapy (PDT) is a treatment for cancer, and for certain non-cancerous diseases that are generally characterized by overgrowth of unwanted or abnormal cells (Milla et al. 2013). Clinical trials continue to expand the role of PDT in cancer and in the treatment of localized microbial infections, as reviewed in (Brown et al. 2000; Agostinis et al. 2011). Protoporphyrin IX (PpIX) is an endogenous photosensitizer used for PDT (Kennedy and Pottier 1992), accumulated in the tumor tissue after the exogenous application of 5-aminolevulinic acid (ALA). Molecular mechanisms of photodynamic action result from generation of oxidative stress. In the presence of molecular oxygen, light of appropriate wavelength excites the photosensitizer that undergoes two

Correspondence to: Dan Sun, Institute of Photonics \& PhotoTechnology Northwest University, Xi'an, 710069, China E-mail: sund@nwu.edu.cn types of reactions (Castano et al. 2006; Garland et al. 2009). In type 1 reactions, excited photosensitizer reacts directly with organic cellular substrates to form radical anions or radical cations that may react further with molecular oxygen to produce reactive oxygen species (ROS) (Ion 2010; Glasauer et al. 2014), resulting in target cell death either through necrosis or apoptosis (Woods and Chandel 2004). In type 2 reactions, the excited photosensitizer transfers its energy directly to oxygen (already a triplet in its ground state) to form highly reactive but short-lived singlet oxygen $\left({ }^{1} \mathrm{O}_{2}\right.$ ) (Castano et al. 2005; Ogilby 2010). Both pathways can occur simultaneously and the ratio between them depends on the photosensitizer and the nature of the substrate. However, direct and indirect evidence supports a prevalent role for singlet oxygen in the molecular processes initiated by PDT (Agostinis et al. 2011; Niedre et al. 2002).

Consumption of fruits and vegetables is known to lower the risk of several diseases. Formononetin (7-hydroxy-3(4methoxypheny) chromone or 4 methoxy daidzein, Fig. 1) 


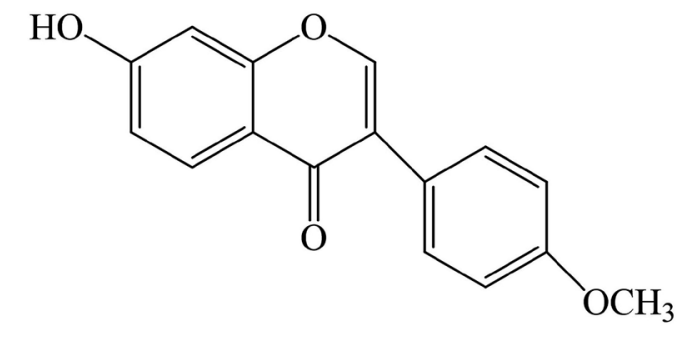

Figure 1. Chemical structures of formononetin.

is a soy isoflavonoid that is found abundantly in traditional Chinese medicine Astragalus mongholicus (Bunge) and Trifolium pretense L. (red clover) (Wu et al. 2010). They belong to the family Leguminosae. The extract of these herbs has been used clinically to treat different diseases including cardiovascular diseases in China for a long time (Wang et al. 2002; Lei et al. 2003). In addition, formononetin possesses hypolipidemic properties (Siddiqui and Siddiqi. 1976), mammary gland proliferation function (Wang et al. 1995) and antioxidative and estrogenic effects (Mu et al. 2009).

The mechanism of PDT exerted on tumor cell killing is the production of ROS. These oxidative actions may be modified by the phytochemicals present in food. Although studies involving use of antioxidants during cancer therapy are promising, research on this topic is still scarce and controversial (González et al. 2005; Gonzalez and Miranda-Massari 2006; Ozben 2007). Studies indicate that supplementation with dietary antioxidants may improve the efficacy of radiation therapy by increasing tumor response and decreasing some of its toxicity on normal cells (Prasad et al. 2001). The other suggests that dietary antioxidants should not be used during radiation therapy, because they would protect cancer cells against radiation damage (Salganik 2001). Each of these is based on different conceptual frameworks that are derived from results obtained from specific experimental designs, and thus, each may be correct within its parameters.

Formononetin has antioxidant properties and it was popular in diet and medicine (Siddiqui and Siddiqi 1976; Wang et al. 2002; Lei et al. 2003; Wu et al. 2010). It should be noticed that any antioxidant found to reduce toxicity of tumor therapy on healthy tissue has the potential to decrease effectiveness of cancer therapy on malignant cells. To assess whether formononetin interferes with PDT treatment, the present study investigated the antioxidant activity of formononetin and demonstrated the influence of formononetin on PDT. This study could lead to a better understanding of their mechanisms of antioxidants applicability in PDT and found which food consumption during PDT did not decrease the effectiveness of cancer therapy.

\section{Materials and Methods}

\section{Chemical reagents}

L-glutamine, trypan blue, 5-aminolevulinic acids and formononetin were purchased from Sigma-Aldrich Co., Ltd. (USA), while RPMI-1640 medium was from Gibco Co., Ltd. (USA). Dimethyl sulfoxides (DMSO), penicillin and streptomycin were obtained from Solarbio (China). Newborn calf serum (NCS) was from Sijiqing (China). Annexin V-FITC-PI Apoptosis Detection Kit was obtained from centre-Bio Co., Ltd. (China). All of the chemicals used in the present study were of analytical grade and purified water used throughout the experiments.

\section{Equipment}

Apoptosis was analyzed on a four-color fluorescence capability FACScalibur flow cytometer (BD Biosciences, USA). The fluorescence spectra were measured with the 970CRT fluorophotometer (Shanghai SANCO Instrument Co., Ltd, China). The fluorescence images of comet assay were examined with a fluorescence microscope (Olympus, Japan). The radiation source was a xenon lamp (USHIO, Japan).

\section{Cell treatment}

K562 cells were cultured in RPMI 1640 medium supplemented with $10 \%(\mathrm{v} / \mathrm{v})$ newborn calf serum, $1 \%(\mathrm{v} / \mathrm{v})$ L-glutamine and 100 units $/ \mathrm{ml}$ antibiotics (penicillin and streptomycin) at $37^{\circ} \mathrm{C}$ in $5 \% \mathrm{CO}_{2}$ and $95 \%$ air. Formononetin was dissolved in $100 \%$ DMSO and stored at $-20^{\circ} \mathrm{C}$. For the cell growth assay, cells were seeded into six-well plates at a density of $1 \times 10^{5}$ cells $/ \mathrm{ml}$ and were treated with formononetin or with DMSO only (as control) in triplicates. The final concentration of DMSO was kept at less than $0.05 \%$. For the dose-dependent experiment, cells were treated with formononetin for $24 \mathrm{~h}$, respectively. For the time-dependent experiment, cells were treated with formononetin and detected at 12, 24, 36 and $48 \mathrm{~h}$.

\section{Photodynamic treatment}

Photodynamic treatment was carried out according to the previous report (Zhang and Zhang 2004). PDT was performed by the administration of ALA with light fluencies. Additional samples were treated with light only (light control). Dark control samples contained neither ALA nor light. K562 cells were stained in the dark at room temperature incubated for $4 \mathrm{~h}$ with $1 \mathrm{mM}$ ALA at $37^{\circ} \mathrm{C}$. Light device (xenon lamp, 400-800 $\mathrm{nm}$ ) was then used for whole face irradiation at the light intensity of $350 \mathrm{~mW} / \mathrm{cm}^{2}$ and a light doses of $105 \mathrm{~J} / \mathrm{cm}^{2}$ at $37^{\circ} \mathrm{C}$. Cells were incubated with formononetin for $20 \mathrm{~min}$ at $37^{\circ} \mathrm{C}$ before PDT irradiation. 


\section{Cell viability assay}

K562 cells $\left(1 \times 10^{5}\right.$ cells $\left./ \mathrm{ml}\right)$ were seeded into 6-well plates at $37^{\circ} \mathrm{C}, 5 \% \mathrm{CO}_{2}$. After incubation, cells were stained by $0.2 \%$ trypan blue solution and monitored on a hemacytometer by a light microscopy. The percent of cell survival was calculated as follows: \% Survival $=($ survival $/$ control $) \times 100 \%$.

\section{Determination of malondialdehyde (MDA)}

The measurement of lipid peroxidation was validated by the well-known TBA assay with some modifications as report of Jentzsch et al. (1996). To assay the lipid peroxidation, the colored MDA-TBA adduct, formed in the reaction of MDA with TBA and acidic conditions was measured by a fluorophotometer, which was obtained and the fluorescence intensity at $546 \mathrm{~nm}$ was determined excited at $530 \mathrm{~nm}$. The standards of MDA were prepared by acid hydrolysis of 1,1,3,3-tetramethoxypropane. A calibration curve was used to calculate MDA concentration, and results were expressed in nanograms of MDA per $10^{6}$ cells.

\section{Flow cytometry}

Cell apoptosis was assayed by using Annexin V-FITC-PI apoptosis detection kit from centre-Bio Co., Ltd. (China) according to the manufacturer's instructions. Cells $\left(1 \times 10^{6}\right.$ cells $/ \mathrm{ml}$ ) were washed with PBS and resuspended in binding buffer. Cells solution $(400 \mu \mathrm{l})$ was incubated with $10 \mu \mathrm{l}$ of Annexin V-FITC $(20 \mu \mathrm{g} / \mathrm{ml})$ for $15 \mathrm{~min}$ and $10 \mu \mathrm{l}$ of propidium iodide $(50 \mu \mathrm{g} / \mathrm{ml})$ for another $5 \mathrm{~min}$ at $4^{\circ} \mathrm{C}$ in the dark, and finally analyzed by flow cytometry at room temperature.

\section{Comet assay}

DNA damage was quantified by the comet assay as described previously (Singh et al. 1988). Cell solution $\left(3 \times 10^{5} \mathrm{cells} / \mathrm{ml}\right)$ mixed with same volume of $1 \%$ low melting point agarose in PBS was pipetted on ice precoated with 2\% normal melting point agarose for $10 \mathrm{~min}$. The slides were incubated in lysis buffer for other $1 \mathrm{~h}\left(0^{\circ} \mathrm{C}\right)$ and then incubated in alkaline unwinding buffer for $20 \mathrm{~min}$. Following electrophoresis for $20 \mathrm{~min}$ at $6.28 \mathrm{~V}$ in unwinding buffer, nuclei were stained with $0.02 \%(\mathrm{v} / \mathrm{v})$ ethidium bromide for $20 \mathrm{~min}$ at room temperature. Digital images of 30 cells were randomly captured for analysis by Casp- 2.2 analysis software. "\% DNA in tail" was calculated as the extent of DNA damage.

\section{Statistical analysis}

Data were processed using Excel analysis software (Microsoft Co., Washington, USA) and expressed as means \pm SD. Dif- ferences between the groups were assessed by the two-tailed Student's $t$-test for unpaired samples. Statistical differences with $p<0.05$ were considered significant.

\section{Results}

\section{Cell survival}

To analyze the effect of formononetin on K562 cell growth/ proliferation, we treated K562 cells cultures with different concentrations of formononetin $(0-100 \mu \mathrm{M})$. For the cell growth assay, cells were seeded into six-well plates at a density of $1 \times 10^{5}$ cells $/ \mathrm{ml}$ and were treated with formononetin or with DMSO only (as control) in triplicates. The final
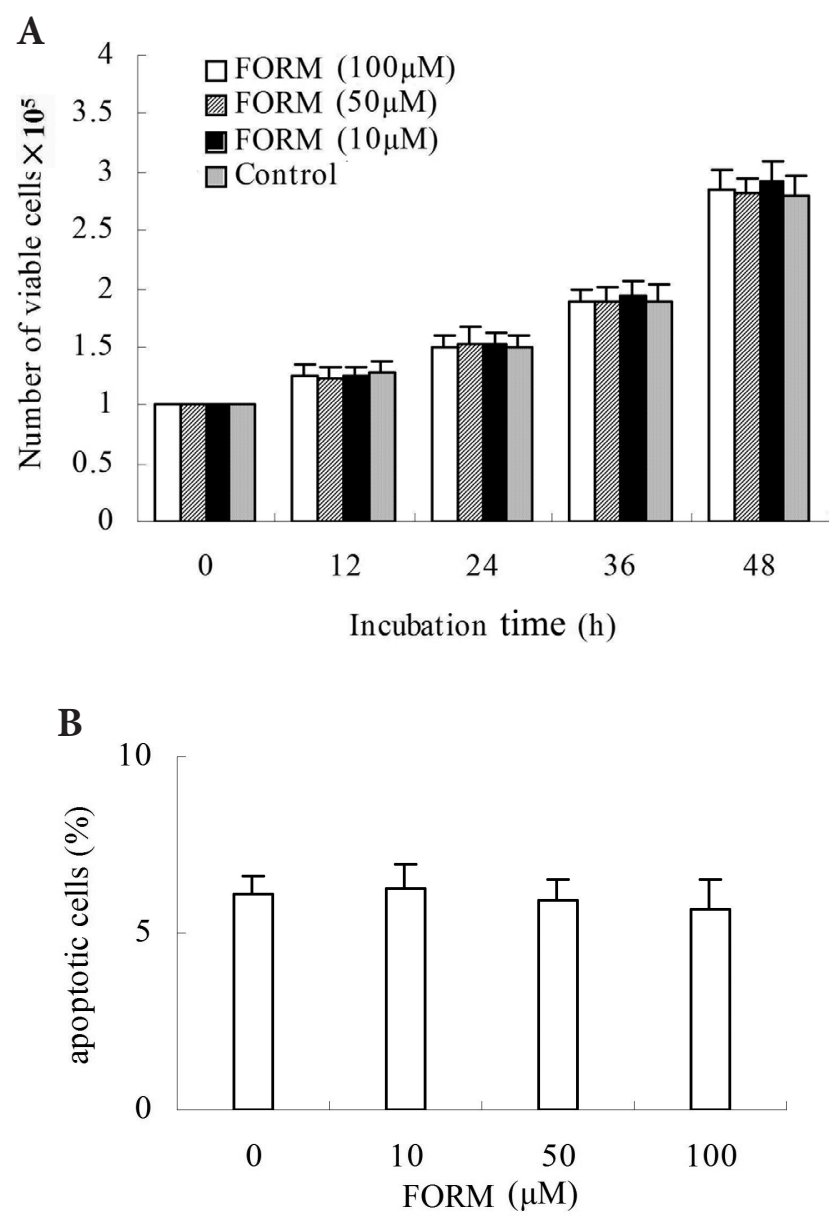

Figure 2. Effects of formononetin (FORM) on cell growth (A) and apoptosis $(\mathbf{B})$. Equal amounts of inoculants $\left(1.0 \times 10^{5}\right.$ viable cells $)$ were seeded in the cultures containing different concentration of formononetin. Cells at each time interval were counted. The data were assessed $24 \mathrm{~h}$ incubation. Calculation of apoptotic cells was provided by flow cytometry analysis. Results represent means \pm SD of three independent experiments. 
concentration of DMSO was kept at less than $0.05 \%$. Cells were treated with formononetin and detected at 12, 24, 36 and $48 \mathrm{~h}$. Cells at each time interval were stained using $0.2 \%$ trypan blue solution and viable cells were counted using a hemacytometer under light microscopy. Cell apoptosis was assayed by using Annexin V-FITC-PI apoptosis detection kit. As showed in Fig. 2A, formononetin did not affect cell survival. After $48 \mathrm{~h}$ incubation, the viable cells in the culture treated with formononetin were same as those in control $(p>0.1)$. While the concentration of formononetin was $100 \mu \mathrm{M}$, the highest concentration used in this study, also not affect cell survival $(p>0.1)$. Cell apoptosis was examined by flow cytometry using Annexin V-FITC-PI Apoptosis Detection Kit. The result indicates that formononetin also could not induce apoptosis in K562 cells $24 \mathrm{~h}$ after incubation compare with control (Fig. $2 \mathrm{~B}, p>0.1$ )

\section{PDT treatment}

To investigate the effect of formononetin on PDT we measured cell survival and cell apoptosis after formononetin and PDT treatment. K562 cells in the exponential phase of growth were harvested at a density of $1 \times 10^{5}$ cells $/ \mathrm{ml}$. Cells were incubated for $4 \mathrm{~h}$ with $1 \mathrm{mM}$ ALA at $37^{\circ} \mathrm{C}$. Then, cells were illuminated with a light intensity of $350 \mathrm{~mW} / \mathrm{cm}^{2}$ and a light doses of $105 \mathrm{~J} / \mathrm{cm}^{2}$ at $37^{\circ} \mathrm{C}$. $\mathrm{K} 562$ cells were incubated with formononetin for $20 \mathrm{~min}$ at $37^{\circ} \mathrm{C}$ before PDT irradiation. The fraction of live cells in the control approach was set as $100 \%$. Calculation of apoptosis was performed after staining the cells with Annexin V-FITC-PI by flow cytometry analysis. The ALA added in the cell culture fluid which $\mathrm{pH}$ was 7.2. We know the $\mathrm{pH}$ of the ALA solution strongly depends on PpIX production in the cells (Krammer and

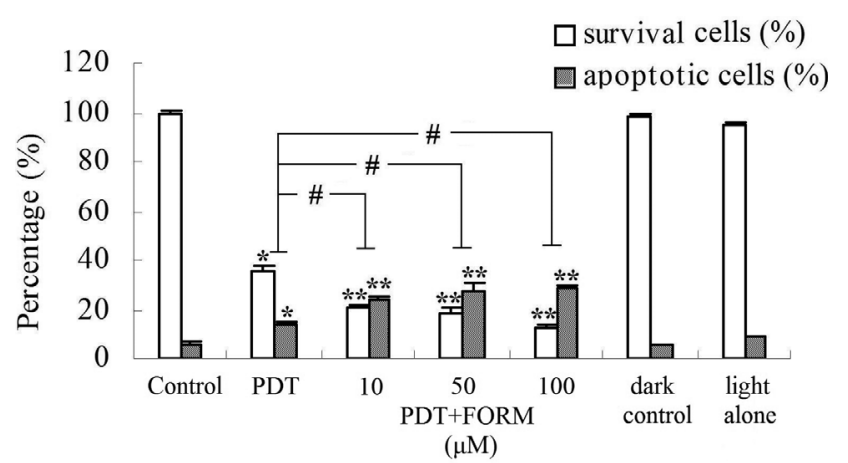

Figure 3. Effects of formononetin (FORM) on cell survival and apoptosis in PDT treatment. K562 cells were incubated 20 min prior PDT irradiation with different concentrations of formononetin. The fraction of live cells in the control approach was set as $100 \%$. Calculation of apoptotic was provided by flow cytometry analysis. Results represent means $\pm \mathrm{SD}$ of three independent experiments. ${ }^{\#} p<0.05 ;{ }^{*} p<0.05$ vs. control; ${ }^{* *} p<0.05 v$ s. ALA-PDT. ALA, 5-aminolevulinic acid.
Uberriegler 1996). The PpIX formation increases with the $\mathrm{pH}$ value of ALA. This $\mathrm{pH}=7.2$ can ensure PpIX production in the cells according to the previous report (Zhang and Zhang 2004).

As shown in Fig. 3, incubation cell with light alone or ALA alone in the dark did not decrease cell viability. After cell with ALA and light, cell survival was significantly decreased. Approximately 35\% cells survived in the PDT. In comparison with untreated cells (control) the increase in apoptosis (approximately 20\%) was observed after PDT treatment. When cells were exposed to formononetin and PDT, a dose-dependent decrease in cell survival was observed compared to cells exposed to PDT alone (Fig. 3, $p>0.05)$. Cell apoptosis were examined by flow cytometry. In comparison with control, the increase in apoptosis (22.87\%) was observed after ALA-PDT treatment. formononetin enhanced the apoptosis induced by ALA-PDT in a dose-dependent manner (Fig. 3, $p>0.05$ ). When formononetin supplemented together with the singlet oxygen quencher sodium azide $\left(\mathrm{NaN}_{3}, 100 \mu \mathrm{M}\right)$ under the same condition, formononetin didn't enhanced the apoptosis in K562 cells induced by ALA-PDT (Fig. 4, $p>0.1$ ). In a word, under the same condition, compared with formononetin supplemented alone (Fig. 3), formononetin supplemented together with the sodium azide suppresses apoptosis (Fig. 4). It can be seen that singlet oxygen quencher sodium azide suppresses apoptosis. Formononetin reduced the cell survival induced by ALA-PDT in a dose-dependent manner $(p>0.05$, Fig. 3 and 4$)$. When formononetin supplemented together with the $\mathrm{NaN}_{3}(100 \mu \mathrm{M})$ at same condition, formononetin could not reduce the cell survival in K562 cells induced by ALA-PDT $(p>0.1)$. It can be seen that singlet oxygen quencher sodium azide suppresses apoptosis and enhances cell survival (Fig. 3 and 4).

\section{Lipid peroxidation and DNA damage}

In parallel with measurement of the influence of formononetin and PDT on cell survival, we examined the oxidative damage and DNA damage after treatments. Oxidative damage induced by PDT was investigated by measurement of malondialdehyde, a marker of lipid peroxidation. Peroxidation of lipids is particularly destructive because the formation of lipoperoxidation products leads to a facile propagation of free radicals and membrane disintegration. Comet assay used to evaluate the potential genotoxic effect induced by PDT on the cells. It has been widely used in toxicology, radiation biology, and was introduced into the field of PDT. Comet assay is a useful technique for the detection of DNA single- and double-stranded breaks, and alkali-labile sites in individual cells after treatment with genotoxins. The major advantages of the comet assay over other methods of measuring DNA damage is that information is acquired about the distribution of DNA damage and 


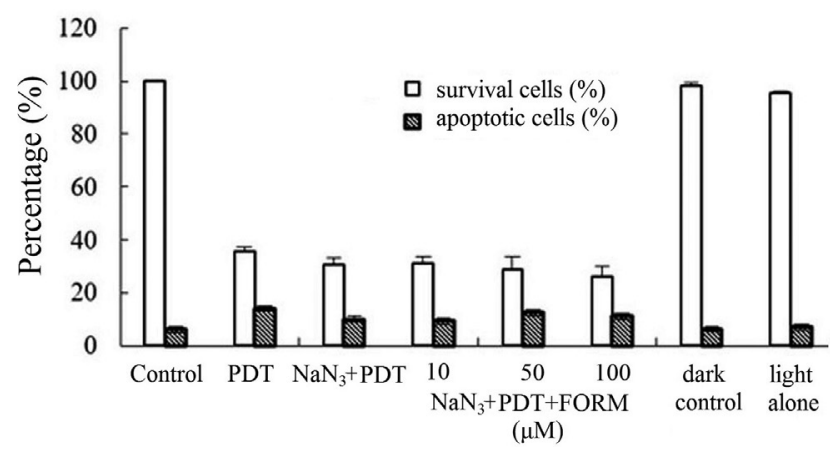

Figure 4. Effects of $\mathrm{NaN}_{3}$ combined with formononetin on apoptotic cells in PDT treatment. K562 cells were incubated 20 min prior ALA-PDT irradiation with different concentrations of formononetin and $\mathrm{NaN}_{3}$. The fraction of live cells in the control approach was set as $100 \%$. Calculation of apoptotic cells was provided by flow cytometry analysis. Results represent means \pm SD of three independent experiments.

repair in individual cells within the population, providing an intracellular distribution of damage.

Result was assessed $24 \mathrm{~h}$ after PDT irradiation. MDA produced was measured to evaluate the lipid peroxidation. MDA amount was determined by measuring the change of fluorescence intensity by the fluorophotometry. DNA damage was quantified with the comet assay. "\% DNA in tail" was calculated as the extent of DNA damage. K562 cells were incubated with formononetin for $20 \mathrm{~min}$ at $37^{\circ} \mathrm{C}$ before PDT irradiation. Formononetin supplementation alone did not affect the MDA concentration and percentage DNA in tail compared to control cells as shown in Fig. $5(p>0.1)$. Significant increase in the amounts of MDA and level of DNA damage was found in K562 cells after PDT treatment compared with control cells or cells treated with ALA dark (dark control) or light alone (Fig. 6, p>0.05). Formononetin enhanced the lipid peroxidation and DNA damage in K562 cells induced by PDT (Fig. 6, $p>0.05$ ).

\section{Discussion}

The isoflavone formononetin possesses antioxidant, antiproliferative, and ROS regulating activities, and have been shown to have protective effects against a number of diseases in humans, including cancer and heart disease (Wang et al. 1995; Wang et al. 2002; Mu et al. 2009). The beneficial effects of formononetin are credited to their antioxidant activities and inhibition of cellular mediators of cell death, protein kinases and eicosanoids has also been postulated (Gopalakrishna and Gandimeda 2002). The present study focuses on the effect of formononetin on PDT in K562 cell. The cell line K562 which is derived from the patient with chronic myelogenous leukemia
(CML) is commonly employed as the "in vitro" model of the blast phase of this disease. PDT includes loading of the target cells with a photosensitizer and subsequent illumination with visible light. Because of cell need illumination with visible light at treatment, PDT is more convenient use in leukemia cell lines compare with solid cancer.

The use of antioxidants during cancer therapy is currently a debated topic because of some contradictory findings (Gonzalez and Miranda-Massari 2006; Frank et al. 2006; Sun et al. 2009). Some data indicate that antioxidants can protect healthy cells and tissues from the damage of free radical without affecting treatment efficacy (Akbas et al. 2006). On the other hand, other researchers suggested that antioxidant decrease the effectiveness of cancer therapy on malignant cells (Richardson et al. 2000; Seifried et al. 2003). Combining these results, further research on antioxidants and chemotherapy are now warranted. The role of antioxidants in PDT is only marginally examined. Few studies have been published to date concerning antioxidants in photodynamic treatment. One research data indicate that discovers that increasing intracellular concentrations of vitamin $\mathrm{C}$ contribute to the resistance of cultured cancer cells to prooxidant treatment modalities as PDT (Frank et al. 2006). Other researchers
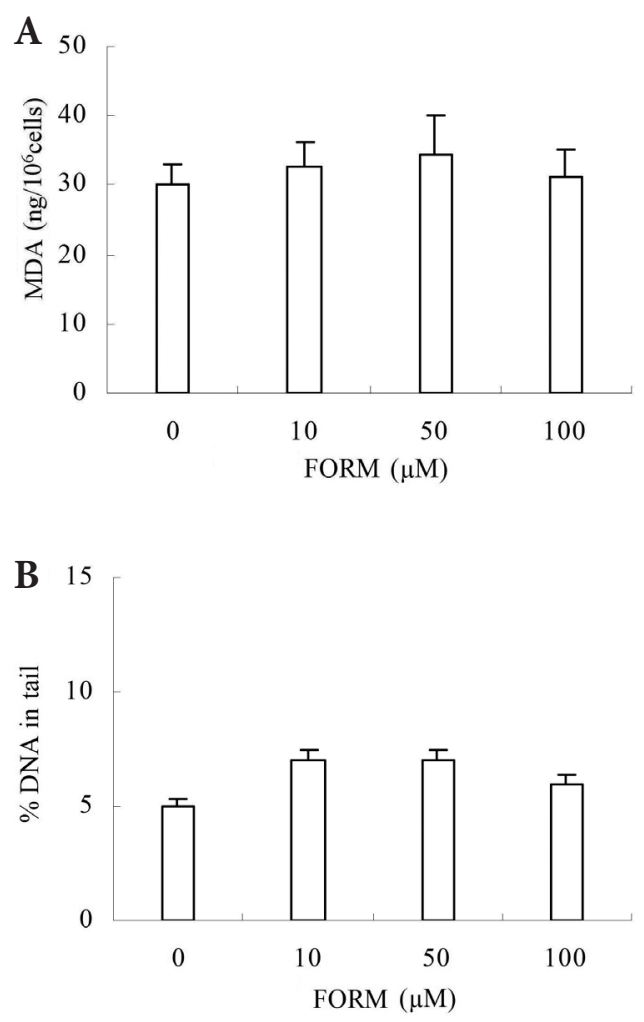

Figure 5. Influence of formononetin (FORM) on lipid peroxidation (A) and DNA damage (B) in K562 cells. Results represent means \pm SD of three independent experiments. MDA, malondialdehyde. 
A

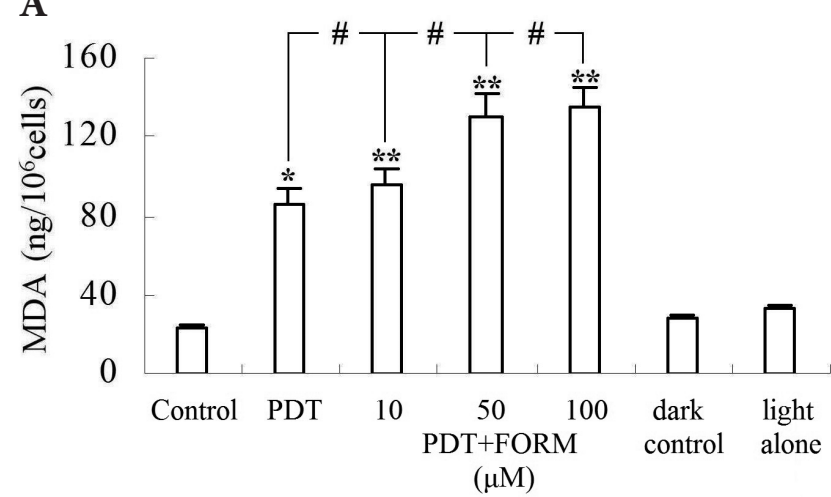

B

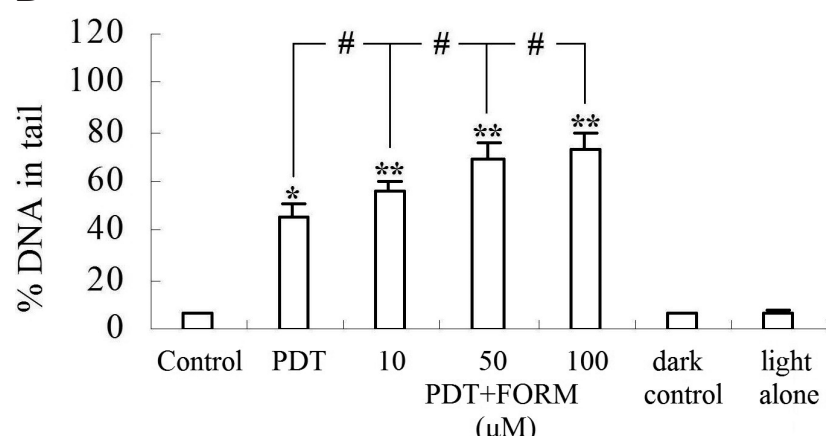

Figure 6. Influence of formononetin (FORM) on lipid peroxidation (A) and DNA damage (B) in K562 cells with PDT treatment. Results represent means \pm SD of three independent experiments. ${ }^{\#} p<0.05 ;{ }^{*} p<0.05 v$ s. control; ${ }^{* *} p<0.05$ vs. ALA-PDT. ALA, 5-aminolevulinic acid; MDA, malondialdehyde.

found that high concentrations of vitamin E enhance the PDT action against HeLa cervical cancer cell line (Al-Sherbini et al. 2009); pre-treatment with tyrosine kinase inhibitor genistein may significantly improve the effectiveness of PDT with hypericin in MCF-7 and MDA-MB-231 breast cancer cells (Ferenc 2010); in PDT-treated cells a p38MAPK-regulated pathway coordinates the p62/NBR1-mediated clearance of cytosolic aggregates and mitigates PDT-induced proteotoxicity (Rubio et al. 2014). Our previous study (Zhang et al. 2012) found the soybean isoflavones genistein and daidzein did not decrease the effectiveness of cancer therapy on malignant cells. The daidzein was metabolized from formononetin. Despite the various reports linking many of the beneficial properties of formononetin to their antioxidant properties, no comprehensive studies have been conducted the effect of formononetin on PDT, which kill tumor cell by production of ROS. The aim of this study was to determine the effect of formononetin on PDT in K562 cell.

Formononetin can likewise induce cancer cell death in different tumor cell type. Auyeung et al. (2010) found formononetin induces apoptosis in human colon cancer HCT
116 cells by activating caspases and down regulating Bcl-2 and Bcl-xL. Ye and colleagues demonstrate that formononetin also induces apoptosis in human prostate cancer cells by inactivating MAPK-Bax signaling pathway (Ye et al. 2012). Chen and colleagues has reported that formononetin inhibits the proliferation of MCF-7 cells and effectively induces cell cycle arrest in the $G_{0} / G_{1}$ phase by inactivating IGF1/PI3K/ Akt pathways and decreasing cyclin D1 expression in human breast cancer cells in vitro (Chen et al. 2011). The same research group also found that formononetin triggers Rasp38 MAPK signaling pathway, and thus provokes apoptosis on estrogen-positive MCF-7 cells (Chen and Sun 2012). As shown in Fig. 1A, after $48 \mathrm{~h}$ of incubation, the viable cells in the cultures treated with formononetin. It did not affect the proliferation of K562 cells. This was contradictory to previous reports that formononetin inhibits the growth of cancer cells (Auyeung et al. 2010). Those results may be due to because the inhibit cancer cells growth effects of isoflavones is often challenging within the experimental model used due to important metabolic phenotype differences observed between cancer cells ( $\mathrm{Gu}$ et al. 2006).

The present study found that formononetin supplementation alone did not affect the cell apoptosis (Fig. 1B), but it increased the apoptosis in K562 cells induced by PDT (Fig. 3). Formononetin supplementation alone did not affect the MDA concentration and the level of DNA damage compared to control cells (Fig. 5), but increased the amounts of MDA and the level of DNA damage in PDT treatment compared to PDT treatment alone (Fig. 6). These results imply that the direct effect of formononetin may not contribute to the enhancement of PDT-induced cytotoxicity in K562 cells and formononetin exhibits a synergistic effect on PDT. The exact reasons for the formononetin enhancement of PDT damage on cancer cells are unknown. Recently, formononetin has been demonstrated to have effects on various cancer cells. Yu reports that formononetin can use as an adjuvant to combine with epirubicin, a well-known anthracycline anticancer drug in HeLa cells to enhance the efficacy of epirubicin (Lo and Wang 2013). These results were similar to our findings that formononetin enhanced the effectiveness of PDT.

Formononetin enhances the PDT-induced cytotoxicity in K562 cells are contradictory to the findings that it is an antioxidant that can scavenge ROS. The contradictory results may be caused that formononetin could increase the amounts of singlet oxygen. It is known that although both superoxide anion and hydroxyl radical are potentially cytotoxic, most of the oxidative damage in PDT is caused by the singlet oxygen (Agostinis et al. 2011). The different ROS have different signaling and damaging capabilities. Since singlet oxygen is highly reactive and cannot interconvert with endogenous ROS species, it is more likely to cause damage than to elicit signal transduction. Yu found that formononetin increased ROS production $\left(\mathrm{H}_{2} \mathrm{O}_{2}\right.$ and $\left.{ }^{1} \mathrm{O}_{2}\right)$ 
but decreased MRP1 and MRP2 expressions, thus supporting the negative correlation between ROS levels and MDR transporter expression (Lo et al. 2013). However, there is no study on the relationship among the effects of formononetin on ROS levels, MDR transporter expression, and apoptosis modulation. Moreover, in this study, the singlet oxygen quencher sodium azide suppresses apoptosis (Fig. 4) in K562 cells induced by PDT with formononetin support this hypothesis. These results imply that singlet oxygen could be involved in the enhance cytotoxicity effects of the formononetin in PDT.

The finding of singlet oxygen involved in the enhance cytotoxicity effects of the formononetin in PDT implied that the contradicted findings on the use of antioxidants during cancer therapy may be resulted from the different sensitization activity of antioxidants on singlet oxygen. The antioxidants which can scavenge singlet oxygen may decrease the effectiveness of PDT (such as vitamin C (Frank et al. 2006). The antioxidants which increase the amounts of singlet oxygen may exhibit a synergistic effect on PDT (such as genistein (Zhang et al. 2012), formononetin (in this research)).

In conclusion, the results proved that formononetin enhanced the cell death in K562 cells induced by PDT. Formononetin supplementation alone did not affect the lipid peroxidation, DNA damage and apoptosis in K562 cells. It increases the lipid peroxidation, DNA damage, and apoptosis in K562 cells induced by PDT. The singlet oxygen quencher sodium azide suppresses apoptosis in K562 cells induced by formononetin in PDT. Consequently, these results implied that formononetin consumption during PDT did not decrease the effectiveness of cancer therapy on malignant cells and singlet oxygen could be involved in this process. This study could lead to a better understanding of their mechanisms of antioxidants applicability in PDT. Further studies could found the effect of antioxidants during cancer therapy to guide the patient's diet.

Acknowledgement. This study was financially supported by "Scientific research fund project of the Education Department of Shaanxi Province (15JK1732)", "Natural Science Foundation of Shaanxi Province (2014JQ1044)" and "The Science Foundation of Northwest University (12NW01)".

\section{References}

Agostinis P., Berg K., Cengel K. A., Foster T. H., Girotti A. W., Gollnick S. O., Hahn S. M., Hamblin M. R., Juzeniene A., Kessel D. et al. (2011): Photodynamic therapy of cancer: an update. CA Cancer. J. Clin. 61, 250-281 https://doi.org/10.3322/caac.20114

Akbas H. S., Timur M., Ozben T. (2006): Concurrent use of antioxidants in cancer therapy: an update. Expert Rev. Clin. Immunol. 2, 931-939 https://doi.org/10.1586/1744666X.2.6.931
Al-Sherbini A. M., ElNoury A. H., ElRouby M. N., Ibrahim T. (2009): VitaminE (a-tocopherol) enhances the PDT action of hematoporphyrin derivatives on cervical cancer cells. Med. Laser. Appl. 24, 65-73 https://doi.org/10.1016/j.mla.2008.11.004

Auyeung K. K., Ko J. K. (2010): Novel herbal flavonoids promote apoptosis but differentially induce cell cycle arrest in human colon cancer cell. Invest. New Drugs 28, 1-13 https://doi.org/10.1007/s10637-008-9207-3

Brown S. B., Brown E. A., Walker I. (2000): The present and future role of photodynamic therapy in cancer treatment. Lancet. Oncol. 5, 497-508 https://doi.org/10.1016/S1470-2045(04)01529-3

Castano A. P., Demidova T. N., Hamblin M. R. (2005): Mechanisms in photodynamic therapy: part two-cellular signaling, cell metabolism and modes of cell death. Photodiagn. Photodyn. Ther. 2, 1-23 https://doi.org/10.1016/S1572-1000(05)00030-X

Castano A. P., Pawel M., Hamblin M. R. (2006): Photodynamic therapy and anti-tumor immunity. Nat. Rev. Cancer. 6, 535-545 https://doi.org/10.1038/nrc1894

Chen J., Sun L. (2012): Formononetin-induced apoptosis by activation of Ras/p38 mitogen-activated protein kinase in estrogen receptor-positive human breast cancer cells. Horm. Metab. Res. 44, 943-948 https://doi.org/10.1055/s-0032-1321818

Chen J., Zeng J., Xin M., Huang W., Chen X. (2011): Formononetin induces cell cycle arrest of human breast cancer cells via IGF1/PI3K/Akt pathways in vitro and in vivo. Horm. Metab. Res. 43, 681-686 https://doi.org/10.1055/s-0031-1286306

Ferenc P., Solár P., Kleban J. (2010): Down-regulation of Bcl-2 and Akt induced by combination of photoactivated hypericin and genistein in human breast cancer cells. J. Photochem. Photobiol. B. 98, 25-34 https://doi.org/10.1016/j.jphotobiol.2009.10.004

Frank J., Flaccus A., Schwarz C. (2006): Ascorbic acid suppresses cell death in rat DS-sarcoma cancer cells induced by 5 -aminolevulinic acid-based photodynamic therapy. Free Radic. Biol. Med. 40, 827-836 https://doi.org/10.1016/j.freeradbiomed.2005.10.034

Garland M. J., Cassidy C. M., Woolfson D., Donnelly R. F. (2009): Designing photosensitizers for photodynamic therapy: strategies, challenges and promising developments. Future Med. Chem. 1, 667-691 https://doi.org/10.4155/fmc.09.55

Glasauer A., Chandel N. S. (2014): Targeting antioxidants for cancer therapy. Biochem. Pharmacol. 92, 90-101 https://doi.org/10.1016/j.bcp.2014.07.017

Gonzalez M. J., Miranda-Massari J. R. (2006): Advances in vitamin $\mathrm{C}$ research. Integr. Cancer. Ther. 5, 7-8 https://doi.org/10.1177/1534735405286108

González M. J., Miranda-Massari J. R., Mora E. M., Guzmán A., Riordan N. H., Riordan H. D., Casciari J. J., Jackson J. A., RománFranco A. (2005): Orthomolecular oncology review: ascorbic acid and cancer 25 years later. Integr. Cancer. Ther. 4, 32-44 https://doi.org/10.1177/1534735404273861

Gopalakrishna R., Gandimeda U. (2002): Antioxidant regulation of protein kinase $C$ in cancer prevention. J. Nutr. 132, 3819-3823 
Gu L., House S. E., Prior R. L., Fang N., Ronis M. J., Clarkson T. B. (2006): Metabolic phenotype of isoflavones differ among female rats, pigs, monkeys, and women. J. Nutr. 136, 1215-1221

Ion R. M. (2010): Derivative UV-Vis spectrophotometry for porphyrins interactions in photodynamic therapy. Anal. Lett. 43, 1277-1286 https://doi.org/10.1080/00032710903518690

Jentzsch A. M., Bachmann H., Fürst P., Biesalski H. K. (1996): Improved analysis of malondialdehyde in human body fluids. Free Radic. Biol. Med. 20, 251-256 https://doi.org/10.1016/0891-5849(95)02043-8

Kennedy J. C., Pottier R. H. (1992): Endogenous protoporphyrin IX, a clinically useful photosensitizer for photodynamic therapy. J. Photochem. Photobiol. B. 14, 275-259 https://doi.org/10.1016/1011-1344(92)85108-7

Krammer B., Uberriegler K. (1996): In-vitro investigation of ALA-induced protoporphyrin IX. J. Photochem. Photobiol. B. 36, 121-126 https://doi.org/10.1016/S1011-1344(96)07358-7

Lei H., Wang B., Li W. P., Yang Y., Zhou A.W., Chen M. Z. (2003) Anti-ageing effect of astragalosides and its mechanism of action. Acta Pharmacol. Sin. 24, 230-234

Lo Y. L., Wang W. J. (2013): Formononetin potentiates epirubicininduced apoptosis via ROS production in HeLa cells in vitro. Chem-Biol. Interact. 205, 188-197 https://doi.org/10.1016/j.cbi.2013.07.003

Milla S. L., Rodriguez M. E., Cogno I. S., Rumie Vittar N. B., Pansa M. F., Lamberti M. J., Rivarola V. A. (2013): Direct and indirect photodynamic therapy effects on the cellular and molecular components of the tumor microenvironment. Biochim. Biophys. Acta 1835, 36-45

Mu H., Bai Y. H., Wang S. T., Zhu Z. M., Zhang Y. W. (2009): Research on antioxidant effects and estrogenic effect of formononetin from Trifolium pratense (red clover). Phytomedicine 16, 314-319 https://doi.org/10.1016/j.phymed.2008.07.005

Niedre M., Patterson M. S., Wilson B. C. (2002): Direct nearinfrared luminescence detection of singlet oxygen generated by photodynamic therapy in cells in vitro and tissues in vivo. Photochem. Photobiol. 75, 382-391 https://doi.org/10.1562/0031-8655(2002)0750382DNILDO2.0. $\mathrm{CO} 2$

Ogilby P. R. (2010): Singlet oxygen: there is indeed some thing new under the sun. Chem. Soc. Rev. 39, 3181-3209 https://doi.org/10.1039/b926014p

Ozben T. (2007): Oxidative stress and apoptosis: impact on cancer therapy. J. Pharm. Sci. 96, 2181-2196 https://doi.org/10.1002/jps.20874

Prasad K., Cole W., Kumar B., Prasad K. (2001): Scientific rationale for using high-dose multiple micronutrients as an adjunct to standard and experimental therapies. J. Am. Coll. Nutr. 20, 450-463S https://doi.org/10.1080/07315724.2001.10719184

Richardson M. A., Sanders T., Palmer J. L., Greisinger A., Singletary S. E. (2000): Complementary/alternative medicine use in a comprehensive cancer center and the implications for oncology. J. Clin. Oncol. 18, 2505-2514 https://doi.org/10.1200/JCO.2000.18.13.2505

Rubio N., Verrax J., Dewaele M., Verfaillie T., Johansen T., Piette J., Agostinis P. (2014): p38MAPK-regulated induction of p62 and NBR1 after photodynamic therapy promotes autophagic clearance of ubiquitin aggregates and reduces reactive oxygen species levels by supporting Nrf2-antioxidant signaling. Free Radic. Biol. Med. 67, 292-303

https://doi.org/10.1016/j.freeradbiomed.2013.11.010

Salganik R. I. (2001): The benefits and hazards of antioxidants: controlling apoptosis and other protective mechanisms in cancer patients and the human population. J. Am. Coll. Nutr. 20, 464-472S https://doi.org/10.1080/07315724.2001.10719185

Seifried H. E., Nald S. S., Anderson D. E., Peter G., Milner J. A. (2003): The antioxidant conundrum in cancer. Cancer Res. 63, 4295-4298

Siddiqui M. T., Siddiqi M. (1976): Hypolipidemic principles of Cicer arietinum: biochanin-A and formononetin. Lipids 11, 243-246 https://doi.org/10.1007/BF02532865

Singh N. P., McCoy M. T., Tice R. R., Schneider E. L. (1988): A single technique for quantification of low levels of DNA damage in individual cell. Exp. Cell. Res. 175, 184-191 https://doi.org/10.1016/0014-4827(88)90265-0

Sun D., Zhang S. J., Wei Y. F., Yin L. F. (2009): Study on antioxidants activities of Mangostin and its effect to K562 leukemia cell in photodynamic therapy. Actc. Bioch. Bioph. Sin. 41, 1033-1043 https://doi.org/10.1093/abbs/gmp099

Wang Y. P., Li X. Y., Song C. Q., Hu Z. B. (2002): Effect of astragaloside IV on T, B lymphocyte proliferation and peritoneal macrophage function in mice. Acta. Pharmacol. Sin. 23, 263-266

Wang W., Tanaka Y., Han Z., Higuchi C. M. (1995): Proliferative response of mammary glandular tissue to formononetin. Nutr. Cancer 23, 131-140 https://doi.org/10.1080/01635589509514369

Woods J. A., Traynor N. J., Brancaleon L., Moseley H. (2004): The effect of photofrin on DNA strand breaks and base oxidation in HaCaT keratinocytes: A Comet assay study. Photochem. Photobiol. 79, 105-113 https://doi.org/10.1111/j.1751-1097.2004.tb09864.x

Wu J. H., Li Q., Wu M. Y., Guo D. J., Chen H. L., Chen S. L., Seto S. W., Au A. L. S., Poon C. C. W., Leung G.P.H. et al. (2010): Formononetin, an isoflavone, relaxes rat isolated aorta through endothelium-dependent and endotheliumin dependent pathways. J. Nutr. Biochem. 21, 613-620 https://doi.org/10.1016/j.jnutbio.2009.03.010

Ye Y., Hou R., Chen J., Mo L., Zhang J., Huang Y., Mo Z. (2012): Formononetin-induced apoptosis of human prostate cancer cells through ERK1/2 mitogen-activated protein kinase inactivation. Horm. Metab. Res. 44, 263-267 https://doi.org/10.1055/s-0032-1301922

Zhang S. J., Sun D., Hao J. B., Wei Y. F., Yin L. F., Liu X. (2012): The effect of dietary soyabean isoflavones on photodynamic therapy in K562 leukemia cells. J. Photochem. Photobiol. B. 110, 28-33 https://doi.org/10.1016/j.jphotobiol.2012.02.006

Zhang S. J., Zhang Z. X. (2004): 5-Aminolevulinic acid based photodynamic therapy in leukemia cell HL60. Photochem. Photobiol. 6, 545-550 https://doi.org/10.1562/MU-03-32.1

Received: September 12, 2016

Final version accepted: January 30, 2017

First published online: August 24, 2017 